\title{
EDITORIAL
}




\section{WHY WE ARE AT WAR}

WE have once or twice been tempted to address the readers of Philosophy on the subject of contemporary events. If ever there was occasion to do so before, there is surely one now.

If not a conflict between philosophers the War on which we are now entering is, as perhaps never before in the whole course of history, one between philosophies which differ fundamentally as to what man is and what he is here for.

To those who have been watching the gathering clouds there were moments of dread lest the issue should be made to appear that of the safety of possessions and of the status quo in their distribution. Whatever the horror of the present moment, we cannot be too thankful that this danger has been averted (though more perhaps by the logic of events than by any conscious logic of our own) and that the issue that was in reality all along at stake has emerged in its true features and proportions.

How often in older wars have we in Great Britain drunk inspiration from the words put by Shakespeare into the mouth of "old John of Gaunt" in "This precious stone set in the silver sea." To-day we are called upon to apply them not to "this realm, this England" alone, but to "this earth" in a wider sense than Shakespeare had in view, set, like England, an island in the sea of the great spaces of the universe. It is this world whose destinies are in the balance threatened by the excursions and alarums of doctrines that would turn it from the great aim of being the abode of a family of nations fitted by their endowments of heart and mind and an ever increasing power over the elements to live together in co-operative unity, to that of making it the cockpit of irreconcilable warring factions It is the glimpse that we have caught of this issue in the confusion of the racing clouds that has nerved us and our allies at last to take our courage in our hands and (even in the midst of the falling away of so many who we hoped would have seen it too) to come forward unmistakably as protagonists in the cause of Humanity. How long the present conflict will last and who will be victors in it is hidden from us. What is not hidden is the unspeakable value of the ideas 


\section{P H I L OSO P H Y}

for which we have taken up arms, the truth of which all the great philosophies and all the great religions of the world have borne witness. We have learned little from these and from our own untrammelled reflections if we do not believe that, however long-drawnout the present conflict may be, and however often it may have to be renewed, the final victory of these ideas is secure. To lose faith in them seems to us to be to lose faith in everything that makes life on this planet worth living. 